\title{
PROFESSOR GALAPAGOS ON THE FLOOR
}

Every so often his colleagues are amazed to see the professor on the floor; the black robe, the pince-nez, the horseshoe of grey hair; the professor lying there, eyes staring.

He seems to have been making his way, see those thin books grasped in his hand, when he suddenly felt that he should lie on the floor.

The dean asks, professor Galapagos, is that you on the floor?

No answer.

This is odd behavior for an academician, professor Galapagos, really. . . And I understand that you will not be embarrassed into resuming your former dignity, sighed the dean.

No answer.

I am willing to do anything you ask, so long as it's not something I don't particularly want to do, sighed the dean.

Then professor Galapagos gets up and goes on his way, still holding those slim books in his hand.

The dean calls after him, professor, I hope you will not hold anything I said against me...

But professor Galapagos is far too busy for what he would consider small talk, chatty gossip...

Of course he will lie on the floor again in a few weeks or a month; it's an acceptable eccentricity; no one knows why it happens, and professor Galapagos doesn't think it important enough to grant an audience or conversation concerning its merits or the lack of same. 